\title{
MEMAKNAI "TORANG SAMUA BASUDARA" (MANAJEMEN DAKWAH BERBASIS KEARIFAN LOKAL DI KOTA MANADO)
}

\author{
Rahman Mantu \\ Institut Agama Islam Negeri Manado, Manado, Indonesia \\ muhammadrahman530@ymail.com
}

\begin{abstract}
Manado as one region which dwelt by moslem society the few has a lot of constraint deeping to develop and carries on religions life, one of it namely activity missionizes, it is caused because attitude streotype (bad think) people non moslem (majority) to moslem is still so strength. To muffle it skilled workers missionizes in each its mission activity tries to dig up local wisdom points that interconnection with prinisip in Islamic teaching that tassammuh (lenient), amongst those is local terminology "Torang Samua Basudara " (We all are brothers). This article utilize teoritik Koentjaraningrat's perspective about formula tripatri culture, where is local wisdom as elemental as social cohesion lasing in multicultural's society. Writer tries to lift this theme because at there are many frequent mission place is utilized as media to attack and sees or behalf with agglomerate another one. skilled workers missionizes then become happening trigger actor it conflict. In research, writer finds that management missionizes to get local wisdom basis this have contribution that really significant in render placating life and on good terms at Manado's city. Management missionizes to get local wisdom basis this ought to continually been developed as one strategy which its aim build interfaith harmonious relationship at region.
\end{abstract}

Keywords:Manajemen Dakwah, Juru Dakwah, Toleran, Kearifan Lokal, Torang Samua Basudara.

Abstrak.Manado sebagai sebuah daerah yang dihuni oleh minoritas masyarakat muslim mempunyai banyak kendala dalam mengembangkan serta menjalankan kehidupan keagamaannya, salah satunya yakni aktivitas dakwah, hal ini disebabkan karena sikap streotype (prasangka buruk) umat non-muslim (mayoritas) terhadap muslim masih begitu kuat. Untuk meredamnya para juru dakwah dalam setiap aktivitas dakwahnya coba menggali nilai-nilai kearifan lokal yang diinterkoneksikan dengan prinisip dalam ajaran Islam yang tassammuh (toleran), diantaranya adalah istilah lokal "Torang Samua Basudara" (Kita semua bersaudara).Artikel ini menggunakan perspektif teoritik Koentjaraningrat tentang rumusan tripatri kebudayaan, dimana kearifan lokal sebagai unsur penguat kohesi sosial dalam masyarakat multikultural. Penulis coba mengangkat tema ini karena di banyak tempat dakwah sering digunakan sebagai media untuk menyerang dan mendiskreditkan kelompok yang berseberangan paham atau kepentingan dengan kelompok yang lain. para juru dakwah kemudian menjadi aktor pemicu terjadinya konflik. Dalam penelitian, penulis menemukan bahwa manajemen dakwah berbasis kearifan lokal ini punya kontribusi yang sangat signifikan dalam mewujudkan kehidupan yang damai dan rukun di kota Manado. Manajemen dakwah berbasis kearifan lokal ini harusnya terus dikembangkan sebagai sebuah strategi yang tujuannya membangun hubungan harmonis antar agama di daerah.

Kata Kunci:Manajemen Dakwah, Juru Dakwah, Toleran, Kearifan Lokal, Torang Samua Basudara. 


\section{Pendahuluan}

Sejarah bangsa telah mengukir berbagai peran mengagumkan yang dimainkan oleh para Ulama (Juru Dakwah).Kerukunan umat beragama pada dekade 1970-1980-an telah berhasil dan terbina dengan baik berkat dukungan mereka, sehingga kerukunan itu dapat mengokohkan persatuan dan kesatuan bangsa yang menjadi modal pembangunan Negara dan bangsa selama ini.Ulama berperan melalui komunikasi interpersonal yang dilakukan melalui ceramah-ceramah agama dan khutbah Jumat di Masjidmasjid.Menurut Mukti Ali, untuk menggerakkan pembangunan di Negara-negara sedang berkembang seperti Indonesia, paling tidak ada tiga kelompok pemimpin yang harus mengambil peranan.Tiga kelompok itu adalah pemimpin resmi (pemerintah), pemimpin tidak resmi (tokoh Agama) serta pemimpin adat.1Penting untuk dicatat bahwa para Juru dakwah ini adalah kelompok terpelajar yang selalu membawa pencerahan kepada

1Departemen Agama, Agama dan Pembangunan di Indonesia, (Jakarta; Biro Humas Depag, 1976), h. 68.
masyarakat.Ini terbukti dengan lahirnya berbagai bentuk lembaga pendidikan baik itu sekolah maupun pondok pesantren.Kesemuanya adalah kontribusi nyata dalam rangka ikut mengantarkan bangsa Indonesia menjadi bangsa yang besar dan maju.Mereka (Juru Dakwah) telah berperan dalam memajukan ilmu pengetahuan, khususnya Islam lewat Jalur dakwah. ${ }^{2}$

Setiap Agama memerintahkan pemeluknya untuk menyampaikan apa yang diketahuinya tentang Agama kepada orang lain atau apa yang lazim disebut dakwah (dalam bahasa Islam) dan misi (dalam bahasa agama Kristen). ${ }^{3}$ Dalam setiap Agama misi,

${ }^{2}$ Abdul Azis Al-Bone, Pengembang Pendidikan Islam dan Khasanah Keagamaan dari Riau dalam Ulama ; Penyebaran Pendidikan dan Khazanah Keagamaan, (Ed) Rosehan Anwar dan Andi Baharuddin Malik, (Cet I, Jakarta; Pringgondani Berseri, 2003), h. 1.

${ }^{3}$ Lebih jauh Thomas W. Arnold mendefinisikan Agama misi atau dakwah dengan ungkapannya; Agama yang di dalamnya terdapat usaha menyebarluaskan kebenaran dan mengajak orang-orang yang belum mempercayainya kepada kebenaran yang diyakini (dan) dianggap sebagai tugas suci oleh pendirinya atau penggantinya. Semangat memeperjuangkan kebenaran sehingga terwujud dalam pikiran, kata-kata dan perbuatannya, suatu semangat yang membuat mereka tidak puas hingga berhasil tertanamnya nilai-nilai kebenaran tersebut dalam jiwa setiap orang sehingga apa yang diyakini sebagai 
semangat menyebarkan Agama kepada orang lain merupakan bagian dari kewajiban. hal ini diperjelas dengan adanya perintah dalam kitab suci masing-masing untuk menjalankan kewajiban tersebut.Dari landasan normatif-doktriner diatas jelas bagaimana Islam mengajarkan dan mensosialisasikan Agama kepada orang lain. dakwah atau misi adalah bagian integral dari Agama, namun dalam praktik penyampaiannya memilki relasi dengan entitas lain. ${ }^{4}$

Menjalankan misi dakwah di Indonesia, yang harus dipahami adalah bahwa kondisi negeri ini yang plural dengan berbagai agama, keyakinan, suku bangsa dan budaya yang berbedabeda. Alwi Shihab, dalam bukunya yang bertajuk Islam Inklusif, mengatakan;

“... kebudayaan Indonesia sangat majemuk dengan beragam agama dan kepercayaan yang dianut penduduknya. Oleh karena itu, pemeliharaan kerukunan dan toleransi menjadi penting bagi persatuan dan kesatuan

kebenaran itu diterima oleh seluruh manusia. Thomas Arnold, Sejarah Dakwah Islam, Terj. A. Nawai Rambe, (Jakarta: Widjaya, 1981), h. 1.

4 Waryono Abdul Ghafur, Kristenisasi "Di Muka Cermin" Dakwah Islam; Telaah Historis-Sosiologis Praktik Kristenisasi di Indonesia, dalam Metodologi Ilmu Dakwah, Andy Dermawan, dkk (ed.), (Cet 1, Yogyakarta; LESFI, 2002), h. 193. bangsa. Perselisihan antar kelompok penganut agama yang berbeda dapat dengan mudah menjadi faktor penyebab konflik dan perpecahan di negara ini..."5

Untuk itu, harus disiapkan sebuah konsep dan strategi yang relevan dengan konteks negara ini supaya ketika melihat perbedaan atau sesuatu yang tampaknya tidak sesuai dengan ajaran agama tak langsung memvonis atau berikap skeptis.Di Indonesia membutuhkan kerja-kerja dakwah yang tepat sesuai dengan keniscayaan multikultur.Sehingga yang menjadi titik fokusnya adalah bagaimana tugas-tugas dakwah itu bisa diimplementasikan di negara yang memiliki ragam budaya.

Masyarakat memiliki ragam budaya dan tradisi lokal yang secarafungsional mampu menjaga situasi lingkungannya agar tetap harmonis,baik dengan sesama manusia maupun lingkungan. Tradisi-tradisi lokaltersebut memiliki makna dan nilai penting diantaranya sebagai acuan tingkahlaku bagi masyarakatnya dalam menjalani kehidupan, termasuk menghadapi perbedaan-perbedaan dalam berinteraksi dengan orang lain yang berbedabudaya. Tradisi-tradisi

5 Lihat Alwi Shihab, Islam Inklusif; Menuju Sikap Terbuka Dalam Beragama, (Cet V, Bandung; Mizan, 1999), h. 258-259. 
lokal tersebut sesungguhnya merupakan pengungkapanpengetahuan lokal (local knowledge) atau kearifan lokal dari suatu masyarakat dalam menanggapi situasi lingkungannya.

Di Indonesia bentuk-bentuk dan model-model dakwah keagamaan kini mulai marak dikritisi banyak pihak, terutama setelah begitu banyaknya peristiwa kerusuhan dengan mengatasnamakan Agama.tidak hanya aktivis keagamaan para akademisi dan kaum intelektul pun ikut bereaksi mencari titik-titik lemah dari berbagai kegiatan dakwah yang berjalan selama ini untuk bisa diperbaiki. Fokus utama yang mendapatkan banyak kritik, Pertama adalah bentuk pelibatan para juru dakwah yang mulai bermain pada wilayah politik praktis. Ini dirasa cukup menganggu netralitas sang juru dakwah yang harusnya menjadi "penengah" diantara berbagai gesekan kepentingan. Kedua kritik dialamatkan kepada polapola dakwah yang bertujuan memperbanyak pengikut agar bisa "menambang emas" (Wealth).Serta sisanya adalah model-model dakwah yang kaku, doktirinal dan jauh dari penanaman nilai-nilai Humanis. ${ }^{6}$

6 Ma`arif Jamuin, Manual Advokasi Resolusi Konflik Antar Etnik dan Agama, (Cet II, CISCORE; Surakarta, 2004), h. 118.
Tulisan ini akan coba memfokuskan pembahasan tentang bagaimana peran para juru dakwah Muslim yang ada di kota Manado dalam menyebarkan ajaran Islam dan mengkoneksikan nilai-nilai lokal dengan Ayat-ayat humanis dalam Al-Quran sebagai sebuah starategi dakwah di daerah yang Multikultur. Juru dakwah yang dimaksud dalam tulisan ini diantaranya meliputi tokoh Agama, aktivis keagamaan, Imam Masjid, dan para Habaib yang ada di Kota Manado.

\section{Konflik dan Peran Juru Dakwah}

Banyak riset yang telah dipublikasi mengenai berbagai macam kasus kekerasan atas nama Agama yang terjadi di Indonesia, salah satunya laporan tahunan kehidupan beragama yang dilakukan oleh CRCS UGM77dalam

7 Laporan Tahunan Kehidupan Beragama di Indonesia telah diterbitkan sebanyak lima kali sejak tahun 2008. Laporanlaporan tersebut mengkaji beberapa masalah utama dalam kehidupan beragama di Indonesia, khususnya dalam pengelolaan keragaman Agama oleh negara maupun masyarakat.Tujuan penyusunan laporan CRCS untuk mendokumentasikan peristiwa-peristiwa penting kehidupan beragama di Indonesia.Dari dokumentasi rutin tersebut diharapkan ada pengetahuan yang memadai mengenai perkembangan kehidupan beragama di negeri ini. Sejak laporan yang pertama, beberapa isu yang menjadi fokus adalah Agama dan kebijakan publik, hubungan antar maupun intrakomunitas Agama, rumah ibadah, isu penodaan Agama, konflik dan kekerasan menyangkut masalahmasalah keagamaan, maupun Agama dalam pemilihan umum. Selain analisis, laporan- 
laporan tersebut mencatat bahwa dalam kurun waktu antara 2008 sampai dengan 2013 aksi kekerasan antar kelompok keagamaan masih terus terjadi, contoh kasus yang paling terlihat dan menjadi isu nasional adalah tindakan intoleran yang dilakukan warga Sunni kepada Syiah di Sampang Madura, serta ada berbagai macam kasus yang menimpa kepada warga Ahmadiyah di beberapa daerah di pulau Jawa. Dalih paling umum yang dituduhkan bahwa Syiah dan Ahmadiyah adalah penganut aliran sesat lagi menyesatkan.Dalam laporan tersebut, di jelaskan berbagai varian kelompok, hingga para aktor yang terlibat dalam aksi kekerasan tersebut.Salah satunya adalah keterlibatan para pemuka agama (Juru dakwah), yang melakukan propaganda melalui "panggung" dakwah.Ini menjadi persoalan serius, karena para juru dakwah ini adalah yang paling sering disebut didalam banyak laporan tahunan keagamaan LSM maupun lembaga riset universitas.

Dalam sejarahnya, di Indonesia, keberadaan para juru dakwah sangat

laporan tersebut mengajukan rekomendasi untuk para pemangku kepentingan terkait. Untuk Mengaksesnya bisa lewat http://crcs.ugm.ac.id/annual-report-top. berpengaruh terhadap perilaku sosialkeagamaan masyarakat. Oleh karena dogma klaim kebenaran, dakwah (dalam Islam) cenderung menjadi stimulan timbulnya misionaris (dalam Kristen), begitu pula sebaliknya misionaris dalam Kristen menjadi stimulan timbulnya dakwah.

Dakwah dimaknai sebagai upaya untuk memperbanyak kuantitas orang Islam yang meniscayakan adanya upaya untuk mengajak orang untuk beragama (berpindah agama) Islam.Demikian halnya misionaris dimaknai sebagai upaya untuk memperbanyak kuantitas umat Kristen yang juga meniscayakan upaya mengajak orang untuk beragama (berpindah agama) Kristen.Padahal, dalam konteks Indonesia, persoalan agama hanyalah salah satu dari sekian problem yang ada di negeri ini.

Konflik-konflik atas nama agama di tanah air, menimbulkan pertanyaan mengenai kontribusi para juru dakwah untuk membangun suatu peradaban yang kuat lagi santun bagi suatu masyarakat mejemuk seperti Indonesia. Pesimisme didasarkan akan gejalagejala menguatnya pandangan sempit pada banyak para juru dakwah yang menganggap bahwa agama yang mereka anut adalah satu-satunya agama yang benar dan karenanya orang lain harus 
mengakui kebenarannya dan itu menjadi objek dakwah, kalau tidak mau menyambut positif dakwah itu, orangorang seperti itu seharusnya tidak diberi hak yang sama dengan hak-hak orang lain dari kelompok itu. Orangorang yang berpendapat seperti ini merasa cukup mampu bekerja dan hidup dengan kelompoknya sendiri, tanpa harus bekerjasama dan berbagi dengan orang-orang lain di luarnya. ${ }^{8}$

\section{Kearifan Lokal: Sebuah Pendekatan}

\section{Dakwah}

Pada tataran empirik dakwah mengandungtiga unsur: penyampai pesan, informasi yang disampaikan, danpenerima pesan. Namun demikian, dakwah secara terminologi mengandung pengertian yang lebih luas, yaitu sebagai aktivitasmenyampaikan ajaran Islam, menyuruh berbuat baik, dan mencegahperbuatan mungkar, serta memberi kabar gembira dan peringatanbagi manusia.Sebagai wacana praksis, dakwah selalu dikaitkan denganfrase 'bijaksana', suatu ungkapan yang menegaskanpenolakan atas setiap jalan kekerasan atau paksaan dalammewujudkan tujuan.

8 Lihat Machasin, Islam Dinamis Islam Harmonis; Lokalitas, Pluralisme, Terorisme, (Cet I, Yogyakarta; LKiS, 2011), h. 245.
Agama idealnya didakwahkan dengan menggunakan pendekatan bi alhikmah (wisdom non violent), mau idhah hasanah (empowerment) dan mujadilah billati hiya ahsan (argumentatif).Sebaliknya dakwah yang dilakukan dengan kekerasan akan 'melukai' batin si penerima dakwah, bahkan berpengaruh terhadap kondisi sosial masyarakat secara keseluruhan. Akhir-akhir ini dakwah yang mengusung ide-ide transnasional (Arabisasi) semakin marak, begitu keras, kaku serta tak ramah dengan kearifan lokal, ini tentu rentan akan konflik di tengah masyarakat.

Dalam teori antropologi (beragama) sebagaimana dikemukakan oleh Red Field ${ }^{9}$ ada istilah great tradition dan little tradition. Great tradition adalah agama yang secara normatif-idealistik yang sifatnya absolut, berlaku secara universal dan sekaligus abstrak. Ketika agama yang normatifidealistik itu dipahami dan dibudayakan oleh suatu komunitas atau suatu bangsa maka akan melahirkan little tradition. Bangsa Indonesia memiliki little tradition dalam beragama yang pasti berbeda dengan little tradition orang Arab atau orang

9 R. Redfield, Peasant Society and Culture, (Chicago: University Chicago Press, 1956), hlm. 12 
Eropa.Karena itulah dakwah yang bersifat arabisasi, eropanisasi, dan pola keberagamaan yang transnasional sangat bersifat kontra produktif bagi pengembangan kearifan

lokal.Metodedakwah dengan menggunakan kearifan lokal jarang sekali di lakukan oleh para juru dakwah, padahal melihat kondisi masyarakat Indonesia yang sangat multikultural, kearifan lokal bisa dijadikan salah satu pendekatan dalam pengembangan dakwah.

Kata kearifan berasal dari kata arif yang berarti 'tahu' dan 'mengetahui'.Dalam diperoleh kata 'mengarifi' yang berarti 'mengetahui', 'memahami'.10Jadi, kearifan sebenarnya dapat diartikan sebagai pengetahuan. Karenanya, definisi kearifan adalah sebagai perangkat pengetahuan yang dapat digunakan untuk menyelesaikan persoalan dan atau kesulitan yang dihadapi dengan cara yang baik dan benar. Kemudian kata 'lokal', secara harfiah kearifan lokal penekanannya adalah tempat, lokalitas, dari kearifan tersebut, sehingga kearifan lokal tidak harus merupakan sebuah kearifan yang telah diwariskan dari generasi ke generasi.Kearifan lokal bisa merupakan

10 W.J.S. Poerwadarminta, Kamus Besar Bahasa Indonesia, Jakarta: Balai Pustaka, 2004), hlm. 60. kearifan yang belum lama muncul dalam suatu komunitas. ${ }^{11}$

Secara substansial, kearifan lokal adalah nilai-nilai yang berlaku dalamsuatu masyarakat.Nilai-nilai tersebut diyakini kebenarannya dan menjadiacuan dalam bertingkah laku sehari-hari masyarakat setempat.Nilainilaikearifan lokal ini dipandang sebagai entitas yang sangat menentukan harkatdan martabat manusia dalam komunitasnya karena di dalamnya berisi unsurkecerdasan kreativitas dan pengetahuan lokal dari para elit dan masyarakatnya.Nilai-nilai kearifan lokal dalam bentuk tradisi maupun normanormasosial di masyarakat secara fungsional dapat memperkuat sistem budayasebagai acuan dalam kehidupan masyarakat, yang kemudian dipercayai dandiakui sebagai elemen penting sehingga mampu mempertebal kohesi sosial diantara warga masyarakat.Dengan demikian kearifan lokal dapat menjadielemen perekat (kohesi) sosial dalam kehidupan lintas agama, lintas kepercayaan,dan bahkan lintas budaya, sehingga dapat memberi warna kebersamaansecara dinamis dan

11 Jumina dan Danang (ed), Kemajuan Terkini Penelitian Kluster Sosial Humaniora, (Yogyakarta: Kantor Wakil Rektor Bidang Penelitian dan Pengabdian Kepada Masyarakat UGM, 2006), hlm. 63. 
damai, terutama dalam masyarakat yangmultikultur. ${ }^{12}$

Kearifan lokal sebagai bentuk kecerdasan lokal masyarakat mengatasipersoalan hidupnya, terutama yang berkaitan dengan hubungan atau interaksisosial, yang dalam realitasnya meniscayakan terjadinya hubunganassosiatif maupun dissosiatif.Terlebih dalam masyarakat yang heterogen danplural, terutama perbedaan agama, memiliki potensi terjadi konflik antarumatberagama.Tantangan semacam ini, tentunya mendorong masyarakatitu sendiri untuk memelihara nilai-nilai tradisi lokal yang mampu menyelesaikanatau meredam munculnya konflik tersebutstrateginya adalah dengan penguatan nilai-nilai kearifan lokal.

Koentjaraningrat

(1984)mengemukakan

apayang disebutnya dengan Tripatri,dimana kebudayaan sebagai perangkat ide atau nilai-nilai. Salah satunya dapat di ketahui dalam wujud pepatah-pepatah

\footnotetext{
12 Joko Tri Haryanto, Kontribusi Ungkapan Tradisional Dalam Membangun Kerukunan Umat Beragama, (Semarang: Jurnal Walisongo Vol. 21, No. 2, 2013), h. 367.
}

dalam bahasa daerah. ${ }^{13}$ Misalnya di Minahasa ada Istilah Sitou Timou Tumou Tou (Manusia Hidup Untuk Memanusiakan Manusia), dari istilah inilah lahir gerakan Mapalus (Gotong Royong) buah dari aplikasi nilai-nilai Sitou Timou Tumou Tou tersebut. Contoh yang lain juga ada di Maluku yaitu Pela Gandong, sebagai nilai lokal yang mengajarkan agar masyarakat Maluku bisa hidup damai di tengah perbedaan baik Agama, suku dan budaya, dan yang paling dikenal seantero tanah air adalah Istilah Torang Samua Basudara (Kita semua bersaudara) dari Kota Manado Provinsi Sulawesi Utara. Istilah atau pepatah ini menjadi semacam "senjata” yang ampuh dalam memelihara kehidupan yang aman dan tenteram di kota "Nyiur Melambai".

\section{Manado: Setting Sosial-Keagamaan}

Manado adalah sebuah kota unik. Berbeda dari banyak kota di kawasan Indonesia lainnya, Manado memiliki hutan, dan pantai yang mengelilingi wilayah urban. letaknya pun di titik terluar bagian utara wilayah negara. Manado berpotensi tidak hanya untuk menjadi pintu gerbang masuk ke dalam

13 Nawari Ismail, Konflik Umat Beragama Dan Budaya Lokal, (Cet I, Bandung; Lubuk Agung, 2011), h. 12-13. 
wilayah Indonesia, tetapi juga untuk menjadi kawasan wisata, bisnis, perdagangan, dan pertemuan antarmanusia dari berbagai latar belakang etnik serta kepercayaan.

Jika berpergian ke kota ini, hal pertama yang mungkin tertangkap mata adalah banyaknya gedung gereja yang dapat dijumpai nyaris di semua jalan utama maupun pelosok-pelosok kota. Namun demikian, umat beragama lain dapat dengan tenang dan hidup damai di kota ini. Bahkan, beberapa jam ke arah barat Manado, di tepi danau Tondano, terdapat sebuah perkampungan yang mayoritas penduduknya adalah orang muslim. Kampung ini dikenal sebagai kampung Jawa. Penduduknya sudah turun temurun menghuni daerah ini.

Kota Manado adalah wilayah urban terbesar di Provinsi Sulawesi Utara, bahkan di kawasan timur Indonesia belahan Utara, jumlah penduduk kota Manado 395.515 jiwa. ${ }^{14}$ Pertumbuhan penduduknya cukup pesat yaitu rata-rata 3,04\% per tahun dengan tingkat pertumbuhan alamiah (faktor kelahiran) kurang lebih 1,50 \% per tahun. Faktor lain yang menyebabkan percepatan pertumbuhan

14 Data dari Badan Pusat Statistik provinsi Sulawesi Utara tahun 2010 jumlah penduduk adalah faktor urbanisasi (migrasi). Selain itu, kecenderungan migrasi sirkuler juga cukup tinggi, diperkirakan sekitar 40.000 orang yang berdomisili di luar kota melakukan aktivitas sehari-hari di Kota Manado.

Komposisi penduduk kota Manado cukup heterogen, baik latar belakang etnik, budaya maupun agama. Mayoritas penduduk berasal dari etnis Minahasa, kemudian Sangihe Talaud, keturunan Cina, Arab, Bugis-Makassar, serta sebagian kecil etnis Mongondow. Selain itu pula terdapat penduduk pendatang dari etnis Jawa, Batak, Padang, Betawi dan lain sebagainya. Agama yang dianut adalah Kristen Protestan, Islam, Kristen Katolik, Advent, Pantekosta, Budha, Hindu dan Konghucu.

Komposisi penduduk kota Manado berdasarkan agama yang dianut, sesuai data yang ada, menunjukkan mayoritas penduduk kota adalah beragama Kristen Prostetan, kemudian penganut agama Islam, lalu Kristen Katolik, di ikuti penganut agama Hindu dan penganut agama Budha pada peringkat terendah. Jumlah penduduk kota Manado berdasarkan data Badan Pusat Statistik (BPS) Sulawesi Utara pada tahun 2010 adalah 445.467 jiwa. 
Berdasarakan angka tersebut $57 \%$ adalah agama Kristen Protestan, 31 \% beragama Islam, disusul Katolik $8 \%$, Hindu 2,5 \%, dan Budha 1,5 \%.

Setelah trans Sulawesi terbuka (awal 1980-an) dan masyarakat transmigrasi mulai berkembang (1970an). Semakin banyak pendatang dari Sulawesi Selatan, Gorontalo dan Jawa yang beragama Islam memasuki wilayah Sulawesi Utara.Mereka datang dengan berbagai maksud dan kepentingan pribadi, pemerintahan dan komunitas. Di mana-mana di Manado, bahkan di seluruh Sulawesi Utara secara umum, mulai ada penduduk yang beragama Islam. Mereka bekerja di pemerintahan, dunia pendidikan dan di sentra-sentra perdagangan kecil, pasar, kaki lima.

Berdasarkan data yang sama di Badan Pusat Statistik Provinsi Sulawesi Utara, menunjukkan bahwa 60 \% rumah ibadah di kota Manado adalah gereja Kristen Protestan, Masjid 26 \%, gereja Katolik 11 \%, vihara 2,5 \% dan Pura 0,5 $\%$.

Dengan adanya keragaman etnis, budaya dan agama di Kota Manado ini maka dapat disimpulkan bahwa kota ini memilki komunitas masyarakat yang sangat plural (majemuk). Keragaman ini berdampak juga terhadap segi kehidupan lainnya seperti adat-istiadat, tradisi, bahasa, bentuk-bentuk kesenian, pola perilaku dan pergaulan masyarakat dan lain sebagainya. Mata pencaharian penduduk pun beragam dari pedagang, Pegawai Negeri Sipil, nelayan, karyawan, dan buruh.

\section{Problematika Dakwah di Kota Manado}

Dalam catatan sejarah kehidupan keagamaan, Manado dulunya di dominasi oleh Kristen yang kemudian menguasai semua aspek baik itu secara kelembagaan maupun aktifitas-aktifitas sosial. Mereka merasa dan menganggap bahwa "Agama Kristen-lah agama dari orang-orang di daerah ini". Pernah dalam kurun waktu cukup lama bahkan sampai sekarang daerah ini dikenal dan dianggap sebagai "daerah Kristen", baik oleh warga masyarakat setempat maupun dari luar. Agama Kristen atau Gereja umumnya masih tetap berada pada mentalitas bahwa "ini daerah Kristen". Warga gereja kurang mengalami tantangan berarti dalam kehidupan bersama dengan yang "lain", homogen, baik etnis maupun agama, sehingga mentalitas "merasa paling dominan" masih hidup dan dihiduphidupkan. Makanya dalam interaksi bersama dengan "yang lain" masih 
berada pada tingkat "kita yang paling berhak untuk hidup di Sulawesi Utara".

Kondisi semacam ini tentu berpengaruh terhadap kehidupan masyarakat muslim di kota Manado, termasuk aktivitas kehidupan keagamaan. memang tidak ada hal yang menjurus kepada konflik besar seperti yang terjadi di daerah lain, tetapi interaksi dan gesekan antar-agama atau antar-etnis (yang biasanya berbeda agama) bisa terjadi sewaktu-waktu yang dapat memicu pada konflik. Apalagi di Minahasa semakin berkembang kelompok-kelompok Kristen "evangelical" atau lebih ekstrim yang "fundamentalis", juga golongan Pentakosta yang semuanya dikenal masih "tertutup" dalam pergaulan plural berbasis agama. Pada saat yang sama, agama Islam semakin berkembang, demikian juga agama Hindu, Buddha dan kini Kong $\mathrm{Hu} \mathrm{Cu}$ (walaupun ketiga agama yang disebut terakhir belum terlalu signifikan). Semuanya adalah bagian dari dinamika perubahan dan perkembangan pluralitas di masyarakat.Mereka adalah warga masyarakat Sulawesi Utara.

Berbagai macam perlakuan diskriminasi yang dialami warga nonmuslim saat ini lebih khususnya di wilayah Jawa, sebut saja misalnya kasus penutupan gereja HKBP dan Yasmin, sangat berpengaruh terhadap pandangan warga Kristiani terhadap masyarakat muslim. kasus demi kasus dalam skup lokal yang berhubungan langsung dengan hubungan antaragama (Islam dan Kristen) mulai terjadi, sentimen agama mulai menjadi menjadi isu, paling update yaitu kasus tidak keluarnya izin penggunaan lapangan Sparta Tikala untuk dijadikan tempat pelaksanaan sholat Idul Fitri pada 2013, lalu kemudian pembangunan Masjid Texas kota yang dipermasalahkan, hingga terjadi aksi massa baik itu yang mendukung dan menolak pembangunan masjid tersebut. tentu peristiwaperistiwa ini menjadi sangat rentan akan konflik antar-agama.

Melihat contoh kasus diatas, para juru dakwah di kota Manado punya tantangan besar dalam melakukan aktivitas dakwahnya, apalagi di daerah yang secara presentasi muslim adalah minoritas. untuk kemudian tidak mendatangkan keresahan sosial, para juru dakwah dituntut agar bisa mencari formulasi baru dalam mengembangkan dakwah yang cocok dengan kondisi sosial-keagamaan tempat dimana dakwah itu dilakukan.

Dimasa-masa awal Islam berkembang di Sulawesi Utara, para 
juru dakwah mendapatkan juga tantangan yang luar biasa baik itu dari pemerintah maupun masyarakat, ini disebabkan karena memang kekuatan Kristen sudah begitu mengakar, ada kekhawatiran akangerakan Islamisasi di Sulawesi Utara secara massif oleh para juru dakwah seperti yang terjadi di wilayah Jawa atau Sumatera. Di beberapa kabupaten di Sulawesi Utara misalnya Bolaang Mongondow yang mayoritas muslim aktivitas keagamaan (dakwah) sudah sangat maju, namun masih dalam lingkup lokal. yang sedikit mengambil perhatian adalah penyebaran penduduk kampung Jawa Tondano di berbagai kabupaten-kota di seluruh Sulawesi Utara, karena masyarakat kampung Jawa Tondano memang diakui sudah sangat mumpuni dalam penguasaan ilmu agama Islam, hal itu tidak terlepas dari peran Kyai Modjo dan KH Ahmad Rifai Kalisalak yang saat pengasingannya mampu mendakwahkan Islam di Minahasa, keberhasilan itu tak lepas juga strategi keduanya dengan melakukan adaptasi sosial melalui media kearifan lokal.

Perpindahan para murid dan keturunan Kyai Modjo dan Kyai Rifai yang paling besar adalah ke kota Manado, yang disponsori oleh Besari Maspekeh Imam pertama Masjid
Mahawu15, Ichwan dan Kosio, kemudian di Dumoga, Bolmong, Josonegoro, Reksonegoro dan Kaliyoso di Gorontalo. Anak keturunan Kyai Modjo dan pengikutnya ini punya pengetahuan Agama yang sangat mumpuni, tidak heran mereka menjadi rujukan masyarakat berbagai daerah di Sulawesi Utara menyangkut persoalan Agama dan dari mereka inilah kemudian gerakan dakwah di Sulawesi Utara khususnya di kota Manado mulai berkembang. Selain Anak Keturunan Kyai Modjo adapula pendatang dari beberapa daerah di Kalimantan, Makassar, dan Jawa ikut mengambil peran menyiarkan Agama Islam. Bahkan mereka mendirikan lembaga-lembaga pendidikan keagamaan seperti pesantren serta Taman Pengajian AlQuran di beberapa tempat di kota Manado sebagai basis melahirkan juru dakwah yang berpikiran inklusif, maka dari lembaga-lembaga itulah para generasi pendakwah di didik hingga saat ini.

15 Mahawu Merupakan salah satu kampung di kecamatan Tuminting kota Manado. Kampung Mahawu ini merupakan daerah yang paling banyak dihuni oleh umat Islam.sehingga kampung ini menjadi pusat dakwah Islam terbesar di Manado. 
Manajemen

Dakwah:

MenegosiasikanNilai

Agama

dan

\section{Kearifan Lokal}

Dakwah agama yang dilakukan para walisongo adalah contoh dakwah agama yang justru menumbuhkan kearifan lokal dan karakter bangsa sendiri. Wali songo bukan hanya berdakwah dengan pendekatan kontekstual dan kultural, tetapi sangat konstruktivistik bagi berkembangnya kearifan lokal. Walaupn wacana fenomenologi belum berkembang pada zaman walisongo, tetapi mereka (walisongo) sangat fenomenoligis dalam berdakwah dan membangun masyarakat. Walisongo bukan hanya mengajari bangsa Indonesia dengan Islam, tetapi juga belajar menjadi bangsa Indonesia. Walisongo telah melakukan Islamisasi sekaligus pribumisasi Islam. ${ }^{16}$

Proses dialog Islam dengan tradisi masyarakat diwujudkan dalam mekanisme proses kultural dalam menghadapi negosiasilokal. Ia tidak diterima apa adanya ketika ditawar oleh khazanahlokal. Di sinilah, Islam dan tradisi masyarakat ditempatkan

16Tobroni, Pengembangan pendidikan karakter bangsa berbasis kearifan lokal, makalah ACIS 2011, (Bangka Belitung), hlm. 851. dalamposisinya yang sejajar untuk berdialog secara kreatif agar salahsatunya tidak berada dalam posisi yang subordinat, yang berakibatpada sikap saling melemahkan.Perpaduan antara Islam dengantradisi masyarakat ini adalah sebuah kekayaan tafsir lokal agar Islamtidak tampil hampa terhadap realitas yang sesungguhnya.Islam tidakharus dipersepsikan sebagai Islam yang ada di Arab, tetapi Islammesti berdialog dengan tradisi masyarakat setempat.

Berbicara tentang pengaruh kultur dan adat lokal dalamkaitannya dengan agama, di sana terlihat adanya pergulatan untukmengompromikan pesan relegius keagamaan yang disinergikandengan muatan lokal. Perjumpaan agama dengan budaya lokal itumengambil banyak bentuk.Pertama, mengalami benturan [clash]yang sampai pada titik di mana budaya setempat dihabisi dan digantiyang baru dengan islamisasi misalnya, yang terjadi di Padang tempodulu.Kedua, ada yang mengambil jalan akomodasi.Artinya adapertemuan saling mengisi dan tidak saling menjatuhkan."Islamditerima tapi sebatas simboliknya.Adapun substansi sepertikepercayaan terhadap leluhur tetap dijaga.Ketiga, mengambil 
bentukhibriditas.Artinya menerima agama tapi separohnya saja, sisanyatradisi setempat.Bentuk ini kemudian biasa dikenal dengan misalnya,Islam Jawa, Islam Banjar, Islam Sasak dan sebagainya. ${ }^{17}$

Dalam konteks lain, negosiasi adalah upaya untukmenghilangkan atau menurunkan nilai daya kekuatan tradisipendatang. Negosiasi berfungsi untuk mengharmonikan yang asingdalam kearifan lokal.Melalui negosiasi, hal-hal baru dari luarwilayah tradisi tidak diterima begitu saja, namun dimodifikasi darikeasliannya, disesuaikan dengan daya terima tradisi.Keberadaannegosiasi tradisi merupakan hal yang alamiah. Tidak ada satu puntradisi yang tidak memiliki negosiasi, yaitu kemampuan untukmengajukan apa yang menjadi milik lokal (sebagai asal)berdampingan atau memaknai apa yang dari luar menjadi sesuatuyang baru (sebagai jadian kreatif). Negosiasi, dalam hal ini, bisaberarti sebagai daya arus balik dalam makna yang lebih lembut.

Dalam proses negosiasi ada upaya perbandingan dengan miliknyasemula, ada proses pertimbangan pragmatis juga ideologis, danniatan untuk

${ }^{17}$ Ahmad Baso, Plesetan Lokalitas: Politik Pribumisasi Islam, Jakarta: Desantara, 2002), hlm. 3. menggunakannya secara baru. Pendeknya, negosiasimengisyaratkan interpretasi kreatif dari pembeli atau pengguna.

Dalam proses ini yang terjadi adalah nilai-nilailslam masuk menjiwai tradisi masyarakat, baik dalam bentuk ritual,kesenian maupun norma-norma. Dengan kata lain, Islam mengisitata cara keagamaan masyarakat lokal. Hasil dari proses negosiasiyang seperti ini adalah layak dipraktikkan di berbagai daerah.dalam bentuk norma-norma misalnya di Sulawesi Utara khususnya kota Manado, ada adagium atau istilah lokal yakni Torang Samua Basudara atau Sitou Tumou Tou. istilah lokal ini kemudian diintegrasikan dengan nilainilai dalam Islam oleh para juru dakwah sebagai materi dakwah.

\section{Penggunaan Istilah Lokal Sebagai Materi Dakwah}

Diantara tradisi masyarakat yang menyimpan keraifan lokal adalah tradisi lisan yang berupa ungkapan-ungkapan atau istilah lokal. Menurut Danajaya, ${ }^{18}$ istilah lokal ini awalnya dinyatakan secara spontan, kemudian menjadi kebiasaan dan dapat dikatakan klise.

18 Samidi Khalim, Tradisi Lisan Masyarakat Jawa, (Semarang: Prima Media Press, 2009), hlm. 3. 
Makna dalam istilah lokal ini dapat bersifat instruktif, inperativ atau preventif. Ciri-ciri lain dari istilah lokal ini adalah:

1. Merupakan alat pencerminan suatu angan-angan yang bersifat kolektif;

2. Sebagai alat pengesahan pranata

3. Sebagai media pendidikan nonformal

4. Sebagai alat pemaksa dan pengawas, agar norma-norma masyarakat dapat dipenuhi.

Istilah lokal adalah kata atau kelompok kata yang memiliki makna kiasan, konotatif, simbolis yang berasal dari tradisi dan folklor lisan, maka istilah lokal mempunyai nilai-nilai yang dijabarkan dari pandangan hidup masyarakat yang membuatnya. 19

Bagi para aktivis dakwah dalam kondisi masyarakat yang majemuk seperti Indonesia (da`i) tak perlu memaksakan "Islam" secara "berlebihan". Pelaksanaan dakwah akan lebih efektif apabila da`i mampu menangkap nilai-nilai universal yang ada dalam Islam, agama-agama non muslim, dan kebudayaan-kebudayaan

19 Joko Tri Haryanto, Kontribusi Ungkapan Tradisional Dalam Membangun Kerukunan Beragama, (Semarang: Jurnal Walisongo, Vol. 21, 2013), hlm. 370. lainnya. Misalnya, nilai kerjasama, nilai kasih sayang, nilai kekeluargaan, dan persamaan yang hampir ada pada setiap agama.

Pendekatan dakwah, baik tabligh (penyiaran), tadzbir (pengorganisasian), tathwir (pengembangan), maupun irsyad (bimbingan), melalui pendekatan dakwah dialogis dan dakwah yang mendayagunakan kearifan lokal adalah solusi metodologis yang tepat dalam membangun dakwah yang lebih ramah dan mengena. Begitu juga dengan materi dakwah, pemahaman terhadap materi-materi dakwah yang lebih aktual dan kontekstual dapa lebih mendekatkan pesan dakwah kepada masyarakat secara persuasif, tanpa beban apalagi tekanan. ${ }^{20}$

Untuk memilih materi dakwah seperti termaksud diatas, disamping ditentukan oleh apresiasi positif kepada yang lain, juga yang terpenting adalah kematangan para da i dalam memahami pesan-pesan atau ide moral secara keseluruhan. Fenomena keberagamaan yang lebih menggambarkan wajah kusut hubungan antarumat beragama ini memang tidak hanya diakibatkan pilihan da`i akan materi dakwahnya saja, tetapi juga oleh faktor lain. Salah

${ }^{20}$ Acep Aripudin, Dakwah Antarbudaya, (Bandung: ROSDA, 2012), hlm. 71. 
satu diantaranya adalah kurangnya pemahaman akan dialektika teks dan konteks yang berakibat pada kesalahan pengamalan sekaligus penyebaran Islam. Jika kesalahan ini masih sebatas pada praksis individual tentu tidak masalah. Persoalan menjadi kompleks ketika kesalahan pemahaman ini dikomunikasikan dan didakwahkan secara luas kepada publik.

\section{FilosofiTorang Samua Basudara}

Torang Samua Basudara adalah kearifan lokal masyarakat Sulawesi Utara.Ciri yang paling menonjol di dalamnya adalah keterbukaan.Hal ini dapat dilihat dari sikap saling menghargai, tolong-menolong atau saling bantu-membantu.Torang samua basudara, kong baku-baku bae, dan baku-baku sayang (kita semua bersaudara, antara yang satu dengan yang lainnya, hiduplah dalam keadaan baik dan saling menyayangi) merupakan pesan moral yang sangat mulia untuk hidup rukun dan damai.

Keterbukaan masyarakat Sulawesi Utara tercermin dalam sikap hidup suka bekerja sama dalam bidang apa saja, namun yang paling menonjol adalah kerja sama dalam bidang pertanian. Dalam kerja sama ini, tiap etnis memiliki nama yang berbeda, namun tujuannya sama, yaitu saling membantu atau tolong-menolong secara bergiliran untuk membuka lahan baru misalnya. Di Minahasa, bentuk kerja sama ini disebut Mapalus; di Sangihe disebut Mapaluse; di Bolaang Mongondow disebut Mopasad.

Walaupun mapalus, mapaluse dan mopasad, merupakan tiga nama dengan sebutan berbeda, namun memiliki tujuan yang sama, yaitu saling bekerja sama dalam menyelesaikan suatu pekerjaan. Semula bentuk kerja sama (mapalus, mapaluse dan mopasad) hanya terbatas di kalangan masyarakat tani, di antaranya kerja sama dalam membuka lahan pertanian baru, menanam padi dan atau memanem padi, atau bentuk pekerjaan lainnya; tetapi kemudian berkembang sampai arisan uang, perkumpulan dalam bentuk rukun keluarga, rukun marga, atau rukun dalam satu sub etnis, perkumpulan atau arisan membawa makanan ke rumah duka secara bergiliran, dan bentuk kerja sama lainnya seperti menjaga tempat ibadah secara bergantian antara pemeluk agama yang yang berbeda.

Dari bentuk kerja sama inilah mulai tercipta rasa saling menghargai, menyayangi dan saling mencitai dalam wujud hidup rukun intern kelompok. Selanjutnya dari hidup rukun intern 
kelompok berkembang sebagai cikal bakal hidup rukun antarkelompok, baik dengan kelompok masyarakat penduduk asli, atau yang sudah berasimilasi maupun dengan kelompok masyarakat pendatang baru.

Memaknai Torang Samua Basudara dalam Al Quran: Perspektif Juru dakwah

Seiring dengan makin berkembangnya masyarakat sulawesi utara yang lebih beragam, maka timbul kesadaran untuk merawat kemajemukan itu secara bersama. Di kalangan masyarakat Manado sejak lama berkembang nilai-nilai persaudaraan yang mengikat antar masyarakat satu dan lainnya, nilai itu tercipta melalui bahasa daerah. Salah satunya adalah jargon "Torang Samua Basudara" yang sudah sangat menasional, Torang Samua Basudara (Kita Semua Bersaudara) ialah simbol ikatan persaudaraan antar masyarakat yang didasarkan pada faktor diluar keturunan (genealogis). Slogan Torang samua Basudara diucapkan pertama kali oleh Gubernur E.E Mangindaan (saat ini menjabat menteri Perhubungan) medio tahun 90-an dimana pada saat itu terjadi konflik di Poso Sulawesi Tengah, slogan ini bertujuan untuk mengkampanyekan semangat persaudaraan di Sulawesi Utara agar tetap menjaga kerukunan dan keamanan di Sulawesi Utara. Pada masa lalu, jika terjadi benturan dan konflik, slogan "Torang Samua Basudara" merupakan yang paling ampuh untuk meredam ketegangan.istilah tersebut mempersatukan masyarakat Sulawesi Utara, sekalipun beda etnis, budaya dan agama. salah satu faktor penting yang menyebabkan kerukunan antar umat beragama di Sulawesi Utara terbina dengan baik adalah peran juru dakwah yang terus mengkampanyekan istilah Torang samua basudara melalui ceramah-ceramah Agama, pengajian dalam lingkup terbatas hingga berbagai forum seminarlintas Agama.

Secara garis besar di dalam ungkapan Torang Samua Basudara terkandung aspek-aspek sebagai berikut: (1) the way of life(cara dan pandangan hidup), (2) menjunjung tinggi rasa toleransi, (3) rasa hormat kepada orang tanpa memandang ras, suku, dan agama, (4) siap membantu sesame tanpa memandang latar belakang, (5) mengedepankan demokrasi.

Istilah Torang Samua basudara ini kemudian sering dijadikan tema 
besar dalam moment hari-hari besar Islam, materi ceramah yang dibawakan oleh para Da`i pun isinya tentang seruan-seruan persaudaraan. Ada beberapa ayat yang dijadikan landasan para juru dakwah ini untuk menegaskan bahwa Torang samua basudara merupakan salah satu pesan yang disampaikan didalam Al-Quran, diantaranya :

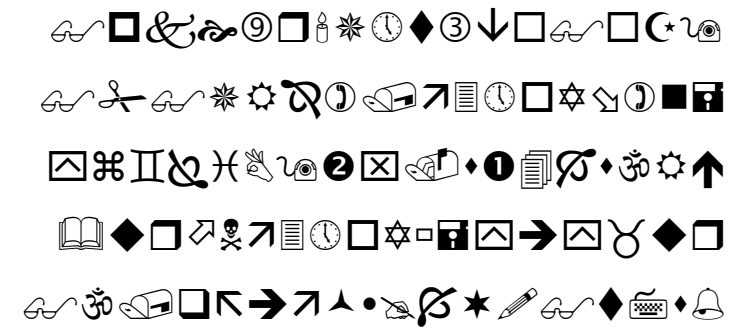

Hai manusia, Sesungguhnya Kami menciptakan kamu dari seorang laki-laki dan seorang perempuan dan menjadikan kamu berbangsa-bangsa dan bersuku-suku supaya kamu saling kenalmengenal.Sesungguhnya orang yang paling mulia diantara kamu disisi Allah ialah orang yang paling taqwa diantara kamu.Sesungguhnya Allah Maha mengetahui lagi Maha Mengenal.
Habib Muchsin Bilfagih ${ }^{21}$ yang dikutip penulis dalam naskah khotbahnya mengemukakan bahwa keragaman adalah kehendak tuhan, ini jelas dalam surat Al-Hujarat [49]: 13 dimana Allah SWT menciptakan manusia dalam jenis laki-laki dan perempuan, lalu menjadikan mereka berbangsa-bangsa dan bersuku-suku agar bisa saling kenal mengenal. Oleh karenanya setiap manusia harus bisa menanamkan sikap toleransi dalam kesehariannya.Melihat substansi ayat ini Torang Samua Basudara jelas merupakan poin utama yang bisa kita ambil untuk terwujudnya kehidupan yang rukun dan damai. ${ }^{22}$

Ayat tersebut merupakan ayat Makkiyah, atau ayat yang diturunkan sebelum nabi Muhammad SAW melakukan hijrah ke Madinah $\mathrm{Al}$ Munawwarah.Sebagai ayat Makkiyah, tentu saja substansinya amat humanis.Ayat tersebut hendak menyapa manusia dalam kapasitas primordialnya

\footnotetext{
${ }^{21}$ Habib Muchsin Bilfagih adalah pendiri sekaligus pengasuh Majelis Al Hikam Cinta Indonesia.Beliau ulama yang cukup dikenal di Sulawesi Utara dan sering mengunjungi beberapa daerah bahkan ke pelosok desa untuk berdakwah.

${ }^{22}$ Naskah Khotbah yang disampaikan pada pelaksanaan sholat Idul Fitri $1434 \mathrm{H}$ di Kelurahan Ketang Baru pada tanggal 8 Agustus 2013.
} 
sebagai manusia. Karena itu, ayat tersebut dimulai dengan, Ya ayyuha alnass (wahai manusia). Cara Al-Quran menyapa seperti itu mempunyai hikmah tersendiri yang harus disingkap.Diantaranya bertujuan untuk mengenalkan kepada manusia tentang pentingnya humanisme. Setiap manusia harus menghormati manusia yang lain. Begitu pula setiap suku harus menghormati suku yang lain. Diantara mereka tidak diperkenankan untuk saling berkonflik dan berperang.Karena dari mereka, manusia yang diciptakan tuhan secara setara, maka mereka harus mampu mengemban pesan kesetaraan tersebut untuk membangun hidup damai dan toleran. ${ }^{23}$ Sejatinya persaudaraan itu tidak bisa dibatasi dengan persoalan teologis semata, hubungan kekerabatan apalagi karena status sosial saja.Ikatan persaudaraan harus dilandasi oleh nilai-nilai humanisme itu sendiri.

Muhammad Bekti salah satu aktivis keagamaan selalu menyerukan kepada umat Islam khususnya yang ada di Kota Manado agar dapat menjaga hubungan baik dengan umat beragama

\footnotetext{
23 Zuhairi Misrawi, Al-Quran Kitab

Toleransi; Inklusivisme, Pluralisme, dan Multikulturalisme, (Cet I, Jakarta Timur: Penerbit Fitrah, 2007), h. 303.
}

lain. di dalam masyarakat majemuk seperti kota Manado yang menghimpun penganut beberapa agama, teologi eksklusivis tidak dapat dijadikan landasan untuk hidup berdampingan secara damai dan rukun. Al Quran jauh sebelumnya telah menegaskan semangat saling menghormati demi tercapainya kehidupan keagamaan yang harmonis.Oleh karena itu merupakan tanggung jawab suci pemuka-pemuka agama untuk memformulasikan teologi yang dapat menciptakan kehidupan imani dalam konteks kemajemukan Agama. Allah swt berfirman dalam Al Qur'an Surat Al An'am/6 : 108,

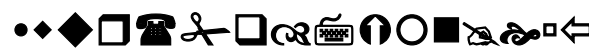

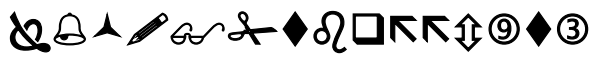
III \&

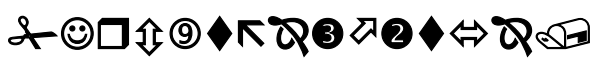

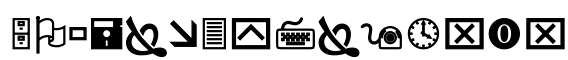
ब6 (3)

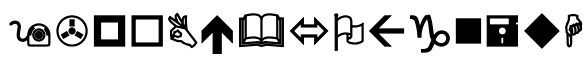

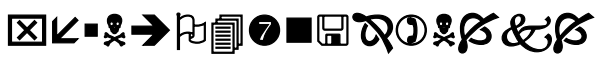
m圈 $6 \Leftrightarrow p_{0} \leftarrow \eta_{0} \pi \rightarrow$ 公 $\gamma \Leftrightarrow 50$

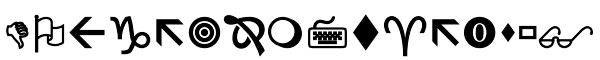

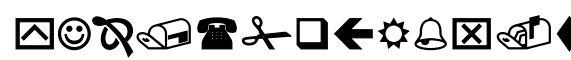

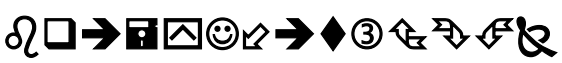

"Dan janganlah kamu memaki sembahan-sembahan yang mereka sembah selain Allah, karena mereka nanti akan memaki Allah dengan 
melampaui batas tanpa pengetahuan.Demikianlah Kami jadikan Setiap umat menganggap baik pekerjaan mereka.kemudian kepada Tuhan merekalah kembali mereka, lalu Dia memberitakan kepada mereka apa yang dahulu mereka kerjakan." 24

Umat Islam oleh Al Quran diharap dapat mengatur langkah hidupnya dengan mengikuti jalan-jalan Tuhan dan hendaknya dapat menghargai dan menghormati pemeluk agama lain. Pada dasarnya pilihan manusia atas jalan hidup yang akanditempuhnya adalah hak asasi yang harus dihormati. Tetapi bukan hal itu berarti meniadakan kepedulian umat Islam kepada umat beragama lain, apalagi dalam hal-hal yang bersifat kemanusiaan. ${ }^{25}$

Kesadaran akan adanya eksistensi Agama-agama lain sangat penting karena ini diakui oleh Al-Quran dalam surah Al-Baqarah ayat 62 ;

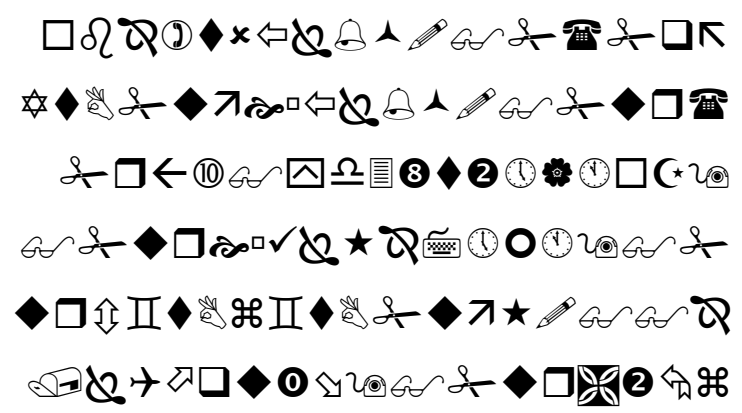

${ }^{24} \mathrm{Al}$-Qur'an dan Terjemahan. "Departemen Agama RI" (Jakarta: Kitab Suci AlQur'an,1971)

25Wawancara dengan Muhammad Bekti, Dosen STAIN Manado, 15 November 2014.

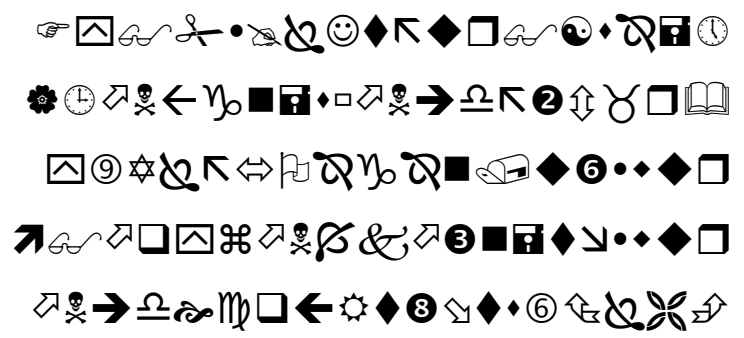
mukmin, orang-orang Yahudi, orang-orang Nasrani dan orangorang Shabiin, siapa saja diantara mereka yang benar-benar beriman kepada Allah, hari kemudian dan beramal saleh, mereka akan menerima pahala dari Tuhan mereka, tidak ada kekhawatiran kepada mereka, dan tidak (pula) mereka bersedih hati.

Titik tekan ayat ini adalah aktivitas kongkret umat beragama yang harus berada dalam kategori amal saleh.Itu berarti, masing-masing Agama dintantang untuk berlomba-berlomba untuk menciptakan kebaikan dalam bentuknya yang nyata. ${ }^{26}$ Untuk menafsirkan ayat ini butuh kerangka metodologis yang kuat.Dibutuhkan peran Juru dakwah untuk mentransformasikan ayat ini secara bebas dengan melihat konteks kekinian yang multi Agama.sehingga juru dakwah mampu menjadi penengah bukan aktor atas peristiwa-peristiwa kekerasan yang mengatasnamakan Agama.

26Moh. Shofan, Pluralisme ; Menyelamatkan Agama-Agama, (Cet I, Yogyakarta ; Samudera Biru, 2011), h. xxvi. 
Agus seorang Da`i muda ${ }^{27}$ menuturkan ada tantangan tersendiri berdakwah ditengah masyarakat yang multikultur. Tema-tema ceramah yang dibawakan sebisa mungkin tidak menyinggung umat beragama yang lain. Daerah ini menjadi titik perjumpaan berbagai Agama, suku, serta lintas budaya, oleh karenanya ajakan-ajakan untuk hidup berdampingan dengan rukun terus dilakukan dalam setiap kesempatan ceramah. Penggunaan Teks ayat Al-Quran dan hadits-hadits yang mengandung makna perdamaian menjadi sesuatu yang wajib dibacakan.

Kegiatan-kegiatan tahunan yang bernuansa keagamaan seperti Maulid Nabi, Isra Mi`raj, 1 Muharram selalu melibatkan orang-orang non-muslim dalam penyelenggaraannya. Baik itu mereka sebagai tamu undangan atau adapula yang berpartisipatif secara langsung ikut menggagas kegiatan tersebut. Ini sudah menjadi hal yang biasa-biasa saja. Saat didaerah lain berdebat tentang boleh atau tidaknya mengucapkan selamat natal, beberapa organisasi keagamaan seperti NU, Muhammadiyah, Sarekat Islam ramairamai membuat baliho dalam ukuran

\footnotetext{
${ }^{27}$ Nama disamarkan, wawancara dilakukan pada tanggal 15 November 2014.
}

besar mengucapkan selamat Natal dan Tahun Baru kepada umat kristiani, tak tanggung-tanggung baliho itu dipampang di gereja-gereja besar yang ada di kota Manado. Saat umat Islam merayakan Idul Fitri pun hal yang sama dilakukan oleh umat non-muslim, Lembaga kegerejaan, organisasi pemuda Kristen, Hindu dan Buddha juga turut mengucapkan selamat dan bersilaturrahmi ke rumah-rumah umat Islam. Kondisi semacam ini tetap terus terjaga hingga sekarang. Penyesuaian materi-materi dakwah dengan kondisi daerah yang majemuk serta menjalin komunikasi dengan umat agama lain secara santun melalui dakwah yang dilakukan oleh para Da`i merupakan strategi yang jitu dalam upaya mempertahankan nilai-nilai toleransi dalam bingkai Torang samua basudara.

K.H. Fauzi Nurani (Ketua MUI Manado) yang dikutip penulis dari hasil wawancara via media online mengatakan Begitu kuatnya nilai-nilai kebasudaraan dalam kehidupan masyarakat kota Manado tak terlepas dari sikap toleransi antar umat beragamanya. Sebab toleransi antar umat beragama yang terjalin dengan baik selama ini, telah membuat pembangunan dalam berbagai subsektor di Sulawesi Utara semakin 
progress. $^{28}$ Jika umat beragama sudah dewasa menyikapi perbedaan disekitarnya, efeknya tentu akan berdampak bukan hanya pada kondisi beragama yang aman tapi juga berbagai sendi kehidupan yang lain.

\section{Penutup}

Sejatinya Islam hadir dengan prinsip cinta (Mahabbah), kebersamaan (ijtima`iyah), persamaan (musawwah), dan persaudaraan (ukhuwah), dan sangat mengakomodir segala bentuk perbedaan.Penanaman prinsip-prinsip ini kepada setiap individu harus terus dilakukan, sehingga umat betul-betul memahami bahwa Islam itu damai, Islam itu toleran.Islam itu tidak berwajah "sangar" seperti yang dituduhkan berbagai pihak terutama dunia barat.Pertanyaannya kemudian ini tugas siapa untuk menyampaikan?jawabannya tentu para pemuka agama (Juru Dakwah) yang punya kapasitas untuk memberikan pengetahuan kepada umat melalui gerakan-gerakan dakwahnya.

${ }^{28}$ http://manado.tribunnews.com/2012 /08/17/kh-fauzi-nurani-momen-untuk-saling memaafkan. diakses pada tanggal 21 November 2014, Pkl 08.00 WIB.
Provokasi damai yang diupayakan oleh para juru dakwah di kota Manado melalui istilah lokal Torang Samua Basudara dengan pendekatan teks suci Al-Quran merupakan strategi yang ampuh mewujudkan kehidupan yang toleran seperti sekarang ini. bukan sesuatu yang mudah menyebarkan ajaran Islam di daerah yang mayoritas beragama nonmuslim. Oleh karena itu formulasi dakwah berbasis kearifan lokal salah satu strategi yang harus terus dikembangkan.semakin majemuk suatu masyarakat, maka tingkat gesekan antara komunitas atau individu yang satu dan yang lain akan makin tinggi. Maka "panggung" dakwah merupakan momentum untuk "menghasut" umat agar terus merawat toleransi.

Berdasarkan elaborasi tersebut dapat disimpulkan bahwakemampuan dakwah Islam untuk beradaptasi dengan budayasetempat, memudahkan dakwah Islam masuk ke lapisan palingbawah dari masyarakat. Tak pelak lagi, Islam sebagai agama yang menyebar ke seluruh penjuru dunia tampil secara kreatif berdialogdengan masyarakat setempat (lokal), berada dalam posisi yangmenerima tradisi masyarakat, sekaligus memodifikasinya menjadibudaya baru yang dapat 
diterima oleh masyarakat setempat danmasih berada di dalam jalur Islam.

\section{Daftar Pustaka}

Anwar dan Malik, Andi Baharuddin, Jakarta; Pringgondani Berseri, 2003.

Azis Al-Bone, Abdu.,Pengembang Pendidikan Islam dan Khasanah Keagamaan dari Riau dalam Ulama; Penyebaran Pendidikan dan Khazanah Keagamaan, (Ed) Rosehan

Arnold, Sejarah Dakwah Islam, Terj. A. Nawai Rambe, Jakarta: Widjaya, 1981.

Abdul Ghafur, Waryono,Kristenisasi "Di Muka Cermin "Dakwah Islam; Telaah Historis-Sosiologis Praktik Kristenisasi di Indonesia, dalam Metodologi Ilmu Dakwah, Dermawan, Andy., dkk (ed.), Yogyakarta; LESFI, 2002.

Aripudin Acep, Dakwah Antarbudaya, Bandung: ROSDA, 2012.

Baso Ahmad, Plesetan Lokalitas: Politik Pribumisasi Islam, Jakarta: Desantara, 2002

Departemen Agama, Agama dan Pembangunan di Indonesia, Jakarta; Biro Humas Depag, 1976.

Data dari Badan Pusat Statistik provinsi Sulawesi Utara tahun 2010.

Data Kantor Departemen Agama Kota Manado Tahun 2009.

Djojosuroto, Kinayati., Dialek dan Identitas Jawa Tondano di Minahasa; Suatu Kajian Historis, sebuah makalah yang dipresentasikan di Universitas Negeri Jakarta (UNJ).

Haryanto,Joko, Tri, Kontribusi Ungkapan Tradisional Dalam Membangun Kerukunan Umat Beragama, Semarang: Jurnal Walisongo Vol. 21, No. 2, 2013.

Ismail, Nawari, Konflik Umat Beragama Dan Budaya Lokal, Bandung; Lubuk Agung, 2011.

Jamuin, Ma`arif, Manual Advokasi Resolusi Konflik Antar Etnik dan Agama, CISCORE; Surakarta, 2004.

Jumina, Danang (ed), Kemajuan Terkini Penelitian Kluster Sosial Humaniora, Yogyakarta: Kantor Wakil Rektor Bidang Penelitian dan Pengabdian Kepada Masyarakat UGM, 2006.

Khalim Samidi, Tradisi Lisan Masyarakat Jawa, Semarang: Prima Media Press, 2009.

Laporan Tahunan Kehidupan Beragama di Indonesia CRCS UGM 2012.

Machasin, Islam Dinamis Islam Harmonis; Lokalitas, Pluralisme, Terorisme, Yogyakarta; LKiS, 2011.

Misrawi, Zuhairi, Al-Quran Kitab Toleransi; Inklusivisme, Pluralisme, dan Multikulturalisme, Jakarta Timur: Penerbit Fitrah, 2007.

Palar, H.B., Wajah Baru Minahasa, Jakarta: Yayasan Gibbon Indonesia, 2009.

Redfield. R, Peasant Society and Culture, Chicago: University Chicago Press, 1956. 
Sachedina,Abdulazis.,Beda Tapi Setara; Pandangan Islam tentang NonIslam, Jakarta; Serambi, 2004.

Shofan, Moh., $\quad$ Pluralisme; Menyelamatkan Agama-Agama, Yogyakarta; Samudera Biru, 2011). Syamsu, Muhammad,Ulama Pembawa Islam di Indonesia dan Sekitarnya, Jakarta; Lentera, 1999.

Tobroni, Pengembangan pendidikan karakter bangsa berbasis kearifan lokal, makalah ACIS 2011, Bangka Belitung: Panitia ACIS, 2011.

Poerwadarminta, Kamus Besar Bahasa Indonesia, Jakarta: Balai Pustaka, 2004.

http://manado.tribunnews.com/2012/ 08/17/kh-fauzi-nurani-momenuntuk-saling-memaafkan. 